Ann. Biol. anim. Bioch. Biophys., 1977, 17 (5 A), 723-736.

\title{
General properties and substrate specificity of an intracellular soluble dipeptidase from Streptococcus diacetilactis
}

\author{
par M. J. DESMAZEAUD, Claude ZEVACO \\ Laboratoire de Biochimie microbienne, I.N.R.A. \\ 78350 Jouy en Josas, France.
}

\begin{abstract}
Summary. Dipeptidase activity from $S$. diacetilactis was isolated and the main activity, Dipeptidase 1, characterized as to substrate specificity, requirements for activity and molecular size. Optimum Dipeptidase I activity was recorded of $\mathrm{pH}$ 7.5-8.0 and molecular weight on gel filtration was estimated to be 51,000 daltons ; it was most stable at temperatures under $50^{\circ} \mathrm{C}$ and at $\mathrm{pH} 7.0-8.0$. This activity was totally inactivated by $0.01 \mathrm{mM}$ EDTA, then reactivated by metal ions $\left(\mathrm{Co}^{++}\right.$and $\left.\mathrm{Zn}^{++}\right)$. This enzyme constitutes a true dipeptidase as it has no tripeptidase or arylamidase activities and does not hydrolyse whole proteins. Studies of substrate specificity show that the enzyme preferentially hydrolyses methionyl-dipeptides (Met-Ala > Met-Val > Met-Ile). The amino-acid composition of Dipeptidase I is comparable with one dipeptidase from Mycobacterium phlei or one renal dipeptidase.
\end{abstract}

\section{Introduction.}

Lactic acid streptococci show complex and variable nutritional requirements. Minimal requirements may involve amino-acids, peptides, purines, pyrimidines, vitamins and occasionally fatty acids and elevated $\mathrm{CO}_{2}$ tension (Deibel and Seeley, 1974). Streptococcus diacetilactis in particular requires arginine or phenylalanine (Reiter and Oram, 1962). Therefore, growth of lactic acid streptococci in milk can generally be stimulated by enzymatic protein hydrolysates (Garvie and Mabbitt, 1956 ; Speck ef al., 1958). The present work realised in our laboratory constitutes part of a more general study in progress to determine the mechanism of peptidic stimulation of lactic streptococcus growth in milk. Since these peptides are a source of amino-acids (Desmazeaud and Hermier, 1972, 1973), their hydrolysis by intracellular proteolytic enzymes must be understood.

On the other hand, little attention has been paid to peptidase activities in streptococcus group N (Exterkate, 1975 ; Mou ef al., 1975 ; Sorhaug and Solberg, 1973), and no true dipeptidase has been purified from $S$. diacetilactis although this type of enzyme was characterized from S. thermophilus (Rabier and Desmazeaud, 1973), Escherichia coli (Brown, 1973 ; Patterson et al., 1973), Mycobacterium phlei (Plancot and Han), 1972 Neurospora crassa (Johnson and Brown, 1974) or eukaryotic cells (Rene and Campbell, 
1969 ; Sjöström ef al., 1973). We isolated a dipeptidasic activity in a previous work (Desmazeaud and Zevaco, 1976) dealing with purification of proteases from a cellular extract of $S$. diacetilactis. The present paper describes the isolation of two dipeptidases and the general properties of the main dipeptidese. Its dipeptide-substrate specificity is also deter mined.

\section{Materials and methods.}

Chemicals and substrates. All chemicals employed were of analytical grade and purchased from Sigma ; DFP (Calbiochem), LL-dipeptides-substrates (Cyclo), Sephadex G-100 and Blue-Dextran 2000 (Pharmacia) excepted. Leu-Leu, Phe-Gly and Met-Leu were used as main substrates for monitoring dipeptidase activity throughout the purification procedure and studying properties.

Organism. Streplococcus diacetilactis strain CNRZ 267. This bacterium was maintained by subculture on sterile skim-milk and preserved by freezing at $-30 \circ \mathrm{C}$.

Cell culture. $35 \mathrm{~g}$ of moist cells were obtained in a fermenter from 7.5 liters of a previously described culture medium of papain-hydrolysed milk (Valles and Mocquot, 1968 ) with a pH maintained at a constant 6.5 value. The bacteria were collected at the end of the exponential growth phase as preliminary results had shown general peptidase activity was maximum at that culture time.

Measurement of protein and enzyme activities.

Proteins : Protein content was determined according to Layne (1957) and Lowry et al. (1951) ; bovine serum albumine was used as a slandard.

Proteolytic activity was determined at $37{ }^{\circ} \mathrm{C}$ by measuring liberated $\alpha$-amino groups by oxidized-insulin hydrolysis after ninhydrin reaction according to Moore and Stein (1954). The reaction mixture contained $0.8 \mathrm{ml}$ substrate at $0.03 \mathrm{p} .100$ concentration in $0.1 \mathrm{M}$ sodium phosphate buffer, $\mathrm{pH} 7.0$, and $0.2 \mathrm{ml}$ of a suitable dilution of enzyme preparation. Incubation time was $30 \mathrm{~min}$.

Dipeptidase activity was determined at $37^{\circ} \mathrm{C}$ by measuring liberated L-amino-acids from various dipeptide substrates after ninhydrin reaction. The reaction mixture contained $0.8 \mathrm{ml}$ substrate $(0.5 \mathrm{mM})$ in $0.1 \mathrm{M}$ sodium phosphate buffer, $\mathrm{pH} 7.0$, and $0.2 \mathrm{ml}$ of a suitable dilution of enzyme preparation. Incubation time was 20 or $60 \mathrm{~min}$.

Tripeptidase activity was determined with the same procedure on different tripeptides.

A unit of dipeptidase activity is defined as $1 \mathrm{micromole} \mathrm{of} \mathrm{substrate} \mathrm{hydrolyzed} / \mathrm{min}$ at $37^{\circ} \mathrm{C}$ and specific activity is defined as enzyme units/min per $\mathrm{mg}$ of protein. Michaelis constants and maximum velocities $\left(37^{\circ} \mathrm{C}\right.$ ) were recorded by means of an extrapolation of the linear portion of Lineweaver-Burk plots. Maximum velocities $V_{m}$ were converted into molecular activities, $k_{\text {cat }}=V_{m} / E$ (mole of substrate hydrolyzed at $37^{\circ} \mathrm{C}$ per sec per mole of enzyme), assuming a molecular weight of 51000.

Aminopeptidase activity was assayed at $37^{\circ} \mathrm{C}$ on Leu-p-nitroanilide substrate according to Roncari and Zuber (1969) and on amino-acid-B-naphthylamides according to Miller and Mc Kinnon (1974). 
Carboxypeptidase activity was assayed at $37^{\circ} \mathrm{C}$ on Z-Gly-AA $\left(\mathrm{AA}_{2}=\mathrm{Arg}\right.$, Leu or Phe) and Z-Glu-Tyr after ninhydrin reaction according to Morihara ef al. (1968).

\section{Purification procedures.}

Step $I=$ Preparation of the cellular extract and elimination of nucleic acids. $35 \mathrm{~g}$ of cells were crushed in a Manton-Gaulin homogenizer, type $15 \mathrm{M} / 8 T A$ (APV-France) under a pressure of 8,000 P. S. I. The cell suspension was then centrifuged at 1,000 $\mathrm{g}$ for $1 \mathrm{~h}$ at $4{ }^{\circ} \mathrm{C}$. The supernatant was preserved and the nucleic acids hydrolyzed by the addition of ribonuclease and deoxyribonuclease according to previously described methods (Desmazeaud and Zevaco, 1976).

Step 2 = 1st chromatography on DEAE-cellulose. After Sepharose 6B gel chromatography, the $800 \mathrm{mg}$ of protein extract in $0.05 \mathrm{M}$ sodium phosphate buffer was adsorbed on a DEAE-cellulose column equilibrated with the same buffer. The column was then washed with the buffer and the proteins eluted with a sodium phosphate buffer gradient according to the previously described methods (Desmazeaud and Zevaco, 1976).

Step $3=2$ nd chromatography on DEAE-cellulose. The $122 \mathrm{mg}$ of the protein extract (previously described) in $5 \mathrm{mM}$ Tris- $\mathrm{HCl}$ buffer $(\mathrm{pH} \mathrm{7.5)}$ was adsorbed on a DEAEcellulose (DE 32, Whatman) column $(2.5 \times 35 \mathrm{~cm})$ equilibrated with the same buffer. The column was then washed with $200 \mathrm{ml}$ of the buffer and the proteins eluted with a linear gradient of $\mathrm{NaCl}(0$ to $0.5 \mathrm{M}$ ) in the buffer. The flow rate was $40 \mathrm{ml} / \mathrm{h}$ (fraction $=10 \mathrm{ml}$ ). Proteolytic activity was determined by oxidized-insulin hydrolysis, and dipeptidase activity by Leu-Leu hydrolysis. In both cases the liberated $\alpha$-amino group from the substrates was measured by ninhydrin reaction.

Step $4=$ Chromatography on Agarose-e-amino caproyl-D-Trp-methylester. After being concentrated 10 times on a Diaflo UM-10 membrane (Amicon) Dipeptidases I and II, previously extracted (Step 3), were purified apart on hydrophobic chromatography gel : Agarose- $\varepsilon$-aminocaproyl-D-tryptophan methyl ester purchased from Miles-Yeda. This gel was equilibrated with $6.6 \mathrm{mM}$ sodium phosphate buffer at $\mathrm{pH} 7.5$, then one dipeptidase was adsorbed on the gel. The $2 \times 9.5 \mathrm{~cm}$ column was washed with the buffer and the proteins eluted with sodium phosphate buffer gradients from $0.02 \mathrm{M}$ to $0.05 \mathrm{M}$ at $\mathrm{pH} 7.5$; flow rate was $15 \mathrm{ml} / \mathrm{h}$ (fraction $=4 \mathrm{ml}$ ).

Polyacrylamide gel electrophoresis. Polyacrylamide gels containing 7 p. 100 acrylamide were prepared at $\mathrm{pH} 9.1$ according to the method of Ornstein (1964) and Davis (1964) ; proteins were stained with Coomassie blue according to Chrambach ef al. (1967). Dipeptidase activity on other gels was localized by the procedure of Lewis and Harris (1967).

Molecular weight defermination. Molecular weight of Dipeptidase I was estimated by the method of Andrews (1964) with a Sephadex G-100 column $(92 \times 2 \mathrm{~cm})$. It was equilibrated with $50 \mathrm{mM}$ sodium phosphcte at $\mathrm{pH}$ 7.5. Proteins were eluted with the same buffer and flow rate was $15 \mathrm{ml} / \mathrm{h}$.

Quantitative amino-acid composition. Determination was carried out using a Beckman multichrome autoanalyzer cfter Dipeptidase I hydrolysis by tridistilled $5.6 \mathrm{~N} \mathrm{HCl}$ in vacuum-sealed tubes for $24 \mathrm{~h}$ and $72 \mathrm{~h}$ at $115^{\circ} \mathrm{C}$. 


\section{Results.}

Isolation and purification of Dipeptidase I and II.

Step 1. The $800 \mathrm{mg}$ of crude extract obtained did not contain any titratable nucleic acids. It had dipeptidase activity, but did not hydrolyse amino-or carboxypeptidase substrates (table 1).

TABLE 1

Purification of dipeptidases from $\mathrm{S}$. diacetilactis Dipeptidase activity was measured on Leu-Leu $0.5 \mathrm{mM}$ at $37^{\circ} \mathrm{C}$ for $20 \mathrm{mn}$ in $0.1 \mathrm{M}$ sodium phosphate buffer at $\mathrm{pH} 7.0$

\begin{tabular}{|c|c|c|c|c|c|c|}
\hline & $\begin{array}{l}\text { Volume } \\
\qquad(\mathrm{ml})\end{array}$ & $\begin{array}{l}\text { Total } \\
\text { activity } \\
\text { (units) }\end{array}$ & $\begin{array}{l}\text { Total } \\
\text { protein } \\
\text { (mg) }\end{array}$ & $\begin{array}{l}\text { Specific } \\
\text { activity } \\
\text { (units/mg) }\end{array}$ & $\begin{array}{r}\text { Yield } \\
\text { p. } 100\end{array}$ & $\begin{array}{l}\text { Purifi- } \\
\text { cation } \\
\text { (fold) }\end{array}$ \\
\hline \multicolumn{7}{|l|}{ Step 1} \\
\hline $\begin{array}{l}\text { a) Elimination of nucleic acid. } \\
\text { b) After Sepharose } 6 \mathrm{~B} \ldots \ldots \ldots\end{array}$ & $\begin{array}{l}200 \\
160\end{array}$ & $\begin{array}{l}2996 \\
2157\end{array}$ & $\begin{array}{r}2800 \\
800\end{array}$ & $\begin{array}{l}1.07 \\
2.69\end{array}$ & $\begin{array}{r}100 \\
72\end{array}$ & $\begin{array}{l}1 \\
2.5\end{array}$ \\
\hline \multicolumn{7}{|l|}{ Sfep 2} \\
\hline $\begin{array}{c}\text { DEAE-cellulose (DE-23) chro- } \\
\text { matography ............ }\end{array}$ & 280 & 1501 & 122 & 12.30 & 50.1 & 11.5 \\
\hline \multicolumn{7}{|l|}{ Step 3} \\
\hline $\begin{array}{l}\text { DEAE-cellulose (DE-32) chro- } \\
\text { matography } \\
\text { Dipeptidase } I \ldots \ldots \ldots \ldots \\
\text { Dipeptidase } I \ldots \ldots \ldots \ldots\end{array}$ & $\begin{array}{l}180 \\
240\end{array}$ & $\begin{array}{l}659 \\
359\end{array}$ & $\begin{array}{r}33 \\
5.5\end{array}$ & $\begin{array}{l}20 \\
65\end{array}$ & $\begin{array}{l}22 \\
12\end{array}$ & $\begin{array}{l}18.7 \\
61\end{array}$ \\
\hline \multicolumn{7}{|l|}{ Step 4} \\
\hline $\begin{array}{l}\text { Agarose-e-amino-caproyl-D- } \\
\text { Trp methyl ester chromato- } \\
\text { graphy } \\
\text { Dipeptidase I. . . . . . . . } \\
\text { Dipeptidase II. . . . . }\end{array}$ & $\begin{array}{l}170 \\
150\end{array}$ & $\begin{array}{l}420 \\
220\end{array}$ & $\begin{array}{l}4.7 \\
2.8\end{array}$ & $\begin{array}{l}89.36 \\
78.57\end{array}$ & $\begin{array}{c}14 \\
7.3\end{array}$ & $\begin{array}{l}83.5 \\
73.4\end{array}$ \\
\hline
\end{tabular}

Step 2. The main protease, Protease A, was eluted at the beginning of the $0.2 \mathrm{M}$ phosphate gradient. Dipeptidase activity overlapping another proteolytic fraction, Protease B, was also separated at this previously described buffer molarity (Desmazeaud and Zevaco, 1976). The active fractions, having dipeptidase activity and representing $122 \mathrm{mg}$ of protein, were combined and dialysed against $5 \mathrm{mM}$ Tris- $\mathrm{HCl}$ buffer at $\mathrm{pH}$ 7.5. Purification ratio was 11.5 fold and 50 per 100 initial units were collected (table 1). 
Step 3. The main dipeptidase, Dipeptidase I, was eluted with a $\mathrm{NaCl}$ concentration of $0.22 \mathrm{M}$; Protease B proteolytic activity still overlapped Dipeptidase I (fig. 1). Dipeptidase II was also separated with a $\mathrm{NaCl}$ concentration of $0.3 \mathrm{M}$. The fraction containing Dipeptidase I represented $33 \mathrm{mg}$ of protein and 22 per 100 of initial units (table 1).

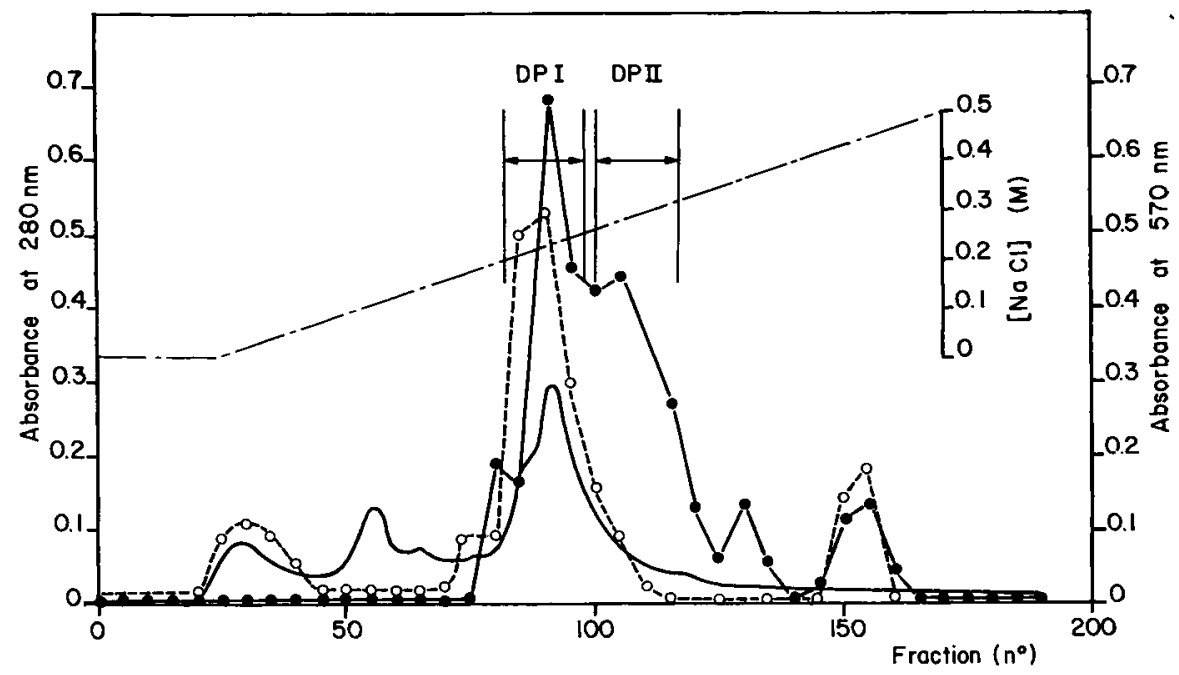

FIG. 1. - DEAE. - cellulose chromatography of dipeptidases from S. diacetilactis.

- - dipeptidase activity was defermined by hydrolysis of Leu-Leu ; $0----0=$ proteolytic activity (protease B) by hydrolysis of oxidized-insulin then in both cases by measuring the liberated $\alpha$-amino group (absorbance at $570 \mathrm{~nm}$ ) as indicated in Materials and methods. Protein elution ( $\longrightarrow$ After protein elution absorbance was measured at $280 \mathrm{~nm} .(\cdot-\cdot-$ ) indicated buffer molarity.

Step 4. Hydrophobic chromatography separated Dipeptidase I and Protease B. Proteolytic activity was not adsorbed on the gel ; Dipeptidase I was thus eluted with $0.016 \mathrm{M}$ phosphate gradient. Dipeptidase II was eluted with the $0.025 \mathrm{M}$ phosphate gradient (fig. 2). Dipeptidase I and II represented 4.7 and $2.8 \mathrm{mg}$ of protein, respectively (table 1).

Analytical polyacrylamide gel electrophoresis indicated that purified Dipeptidase I $(20 \mu \mathrm{g})$ consisted of a single protein band (Experiment B ; fig. 3). A further test of preparation homogeneity $(60 \mu \mathrm{g})$ showed that purified Dipeptidase I, besides producing a main component corresponding to dipeptidase activity against various dipeptides (fig. 3. Experiments LL, LA, LG, ML, PG and HS), evidenced two minor bands (Experiment A ; fig. 3). The general properties of this enzyme were studied without further purification. 


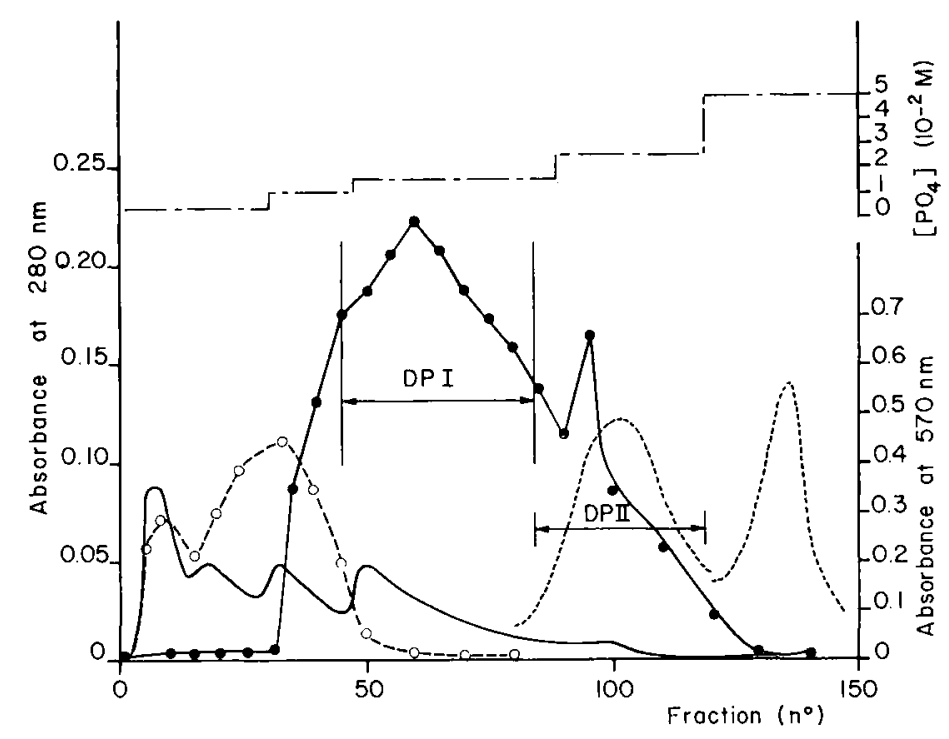

FIG. 2. - Chromatography of dipeptidase on Agarose-e-aminocaproyl-D-Trp methylester.

and - _..- = dipeptidase activity was determined by hydrolysis of Leu-Leu (absorbance at $570 \mathrm{~nm})$.

$0-\cdots=$ proteolytic activity (absorbance at $570 \mathrm{~nm}$ ).

$-\quad=$ protein elution (absorbance at $280 \mathrm{~nm}$ ).

. - - = buffer molarity.

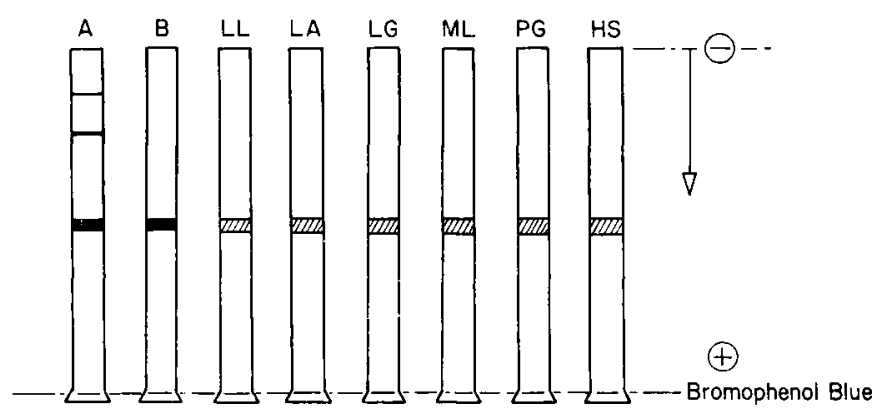

FIG. 3. - Polyacrylamide gel electrophoresis of Dipepfidase I.

$\mathrm{A}=$ experiment with $60 \mu \mathrm{g}$ of Dipeptidase I ; B = experiment with $20 \mu \mathrm{g}$ of Dipeptidase I. After electrophoresis at $\mathrm{pH} 9.1$ the gels were stained with Coomassie blue. Other tubes with $60 \mu \mathrm{g}$ of enzyme displayed dipeptidase localization on gel with various dipeptide substrates ( $L L=$ Leu-Leu, LA = Leu-Ala, LG = Leu-Gly, ML = Met-Leu, PG = Phe-Gly and HS = His-Ser).

\section{General properties of dipeptidase I}

Molecular weight. The apparent molecular weight of the dipeptidase was estimated with a Sephadex G-100 column to be 51000 daltons, as compared to that of trypsin, pepsin and bovine serum-albumin. 
Effect of temperature. The purified Dipeptidase I retained its activity after storage over several months at $-20^{\circ} \mathrm{C}$. It could be kept at $25^{\circ} \mathrm{C}$ for some hours or at $50^{\circ} \mathrm{C}$ for 30 min without becoming inactive (fig. 4); it was slowly inactivated at $55^{\circ} \mathrm{C}$ and rapidly at higher temperatures. Fifty per cent of its activity was lost after $15 \mathrm{~min}$ at $60^{\circ} \mathrm{C}$ and 90 per cent after $10 \mathrm{~min}$ at $65^{\circ} \mathrm{C}$ (fig. 4).

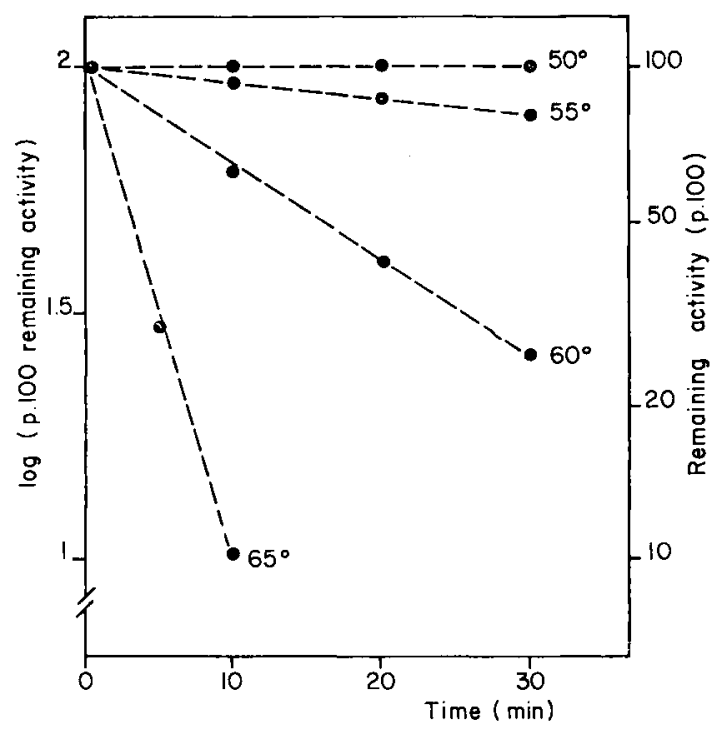

FIG. 4. - Thermal denaturation of Dipeptidase I.

Dipeptidase I $(20 \mu \mathrm{g})$ was incubated at $\mathrm{pH} 7.0$ in $10 \mathrm{mM}$ sodium phosphate buffer. The remaining activity was estimated at $\mathrm{pH} 7.0$ for $20 \mathrm{~min}$ at $37^{\circ} \mathrm{C}$ on Leu-Leu or Phe-Gly and expressed as a percentage of the control on a logarithmic plot.

Effect of $\mathrm{pH}$. Maximum activity was obtained at $\mathrm{pH} 7.5-8.0$ with three dipeptide substrates (fig. 5). Fifty or sixty per cent of this activity (substrate Met-Leu) was measured at $\mathrm{pH} 7.0$ or 8.5 , respectively. Dipeptidase I was quite stable over the $\mathrm{pH}$ range 7.0-8.0. Thirty-seven per cent of the activity was inactivated at $\mathrm{pH} 5.5$ or $\mathrm{pH} 9.5$ after $30 \mathrm{~min}$ at $37^{\circ} \mathrm{C}$ (fig. 5A).

Effect of various inhibitors and metal-ion requirement. Serine protease inhibitors such as DFP and PMSF showed no inhibition against Dipeptidase I. The sulfhydryl protease inhibitor PCMB $0.1 \mathrm{mM}$ or $\mathrm{mM}$ reduced the activity to 80 and 0 per 100 , respectively. Therefore, there is no seryl residue in the active site of Dipeptidase I. Sulfhydryl residues must be important to the activity, although the concentration of $\mathrm{p}$-chloromercuribenzoate used was high. Sulfhydryl protein groups showed various reactions to $\mathrm{PCMB}$.

Addition of $10^{-3} \mathrm{mM}$ EDTA to the reaction mixture reduced the hydrolysis rate of Leu-Leu or Met-Leu to 80 p. 100 as compared to the controls. Addition of $0.01 \mathrm{mM}$ EDTA completely inhibited Dipeptidase I activity. This inhibition can be fully reversed 
by addition of $\mathrm{Co}^{++}$or $\mathrm{Zn}^{++}$. Metal ions such as $\mathrm{Ca}^{++}, \mathrm{Mn}^{++}$or $\mathrm{Mg}^{++}$can reactivate Dipeptidase I to a certain extent (table 2). The results clearly indicate that the enzyme requires a divalent ion for its activity.

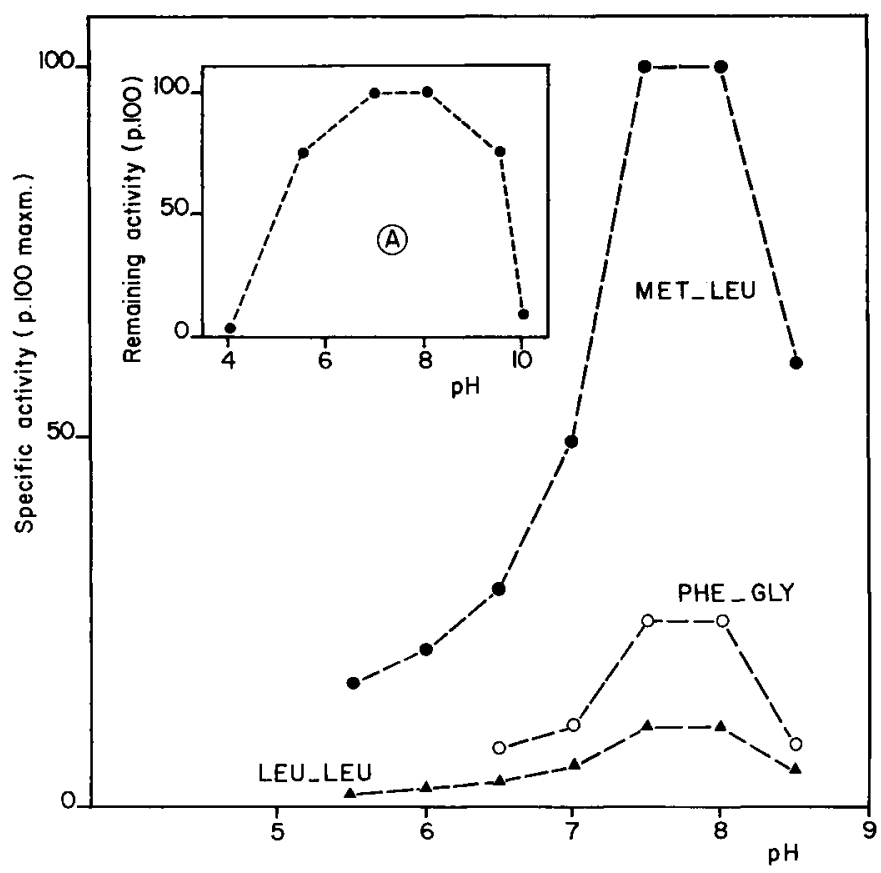

FIG. 5. - Activity and stability (Insert A) of Dipeptidase I as a function of $\mathrm{pH}$.

Dipeptidase activity $(20 \mu \mathrm{g})$ on Met-Leu, Phe-Gly and Leu-Leu $(0.5 \mathrm{mM})$ was tested in $\mathrm{pH}$ range from 5.5 to 8.5 in $0.1 \mathrm{M}$ sodium phosphate buffer. The activity was measured at $37^{\circ} \mathrm{C}$ for $30 \mathrm{~min}$ and expressed as per cent of maximum specific activity on Met-Leu.

Insert $\mathrm{A}=$ Effect of $\mathrm{pH}$ on the stability of Dipeptidase $\mathrm{I}$. The enzyme was incubated for $30 \mathrm{~min}$ at $37^{\circ} \mathrm{C}$ in $10 \mathrm{mM}$ sodium acetate $(\mathrm{pH} 5.5$ to 8.5 ) and $10 \mathrm{mM}$ sodium carbonate buffer ( $\mathrm{pH} 8.5$ to 10.0 ) adjusted to the desired $\mathrm{pH}$. The remaining activity was estimated at $\mathrm{pH} 7.0$ as indicated above and expressed as a percentage of the control.

Substrate specificity. The relative rates of 32 dipeptides hydrolysed by Dipeptidase I are summarized in table 3. Methionyl-alanyl appeared to be hydrolysed at the highest rate. All methionyl-dipeptides were the best substrates with one exception, Met-Glu, which was hydrolysed at a rate comparable to that of Leu-Gly or Phe-Gly (table 3). A wide range of dipeptides was poorly hydrolysed by Dipeptidase I. They contain $\mathrm{N}$-terminal glycine, L-alanine or L-proline (table 3). Some $\mathrm{N}$-terminal glycine or L-alanine dipeptides were not hydrolysed by Dipeptidase I (table 3). This purified enzyme must be classified as a true dipeptidase as it lacks activity against the tested tripeptides. Met-Leu-Gly in particular was not hydrolysed (table 3), though Met-Leu and Leu-Gly were good substrates; it evidenced no activity against aminoacyl-Bnaphthylamides or Leu-p-nitroanilide (table 3). Experiments performed with com- 
TABLE 2

Dipeptidase 1 divalent cations requirement after inhibition for EDTA.

The enzyme was pre-incubated for $15 \mathrm{~min}$. at $37^{\circ} \mathrm{C}$ with $0.01 \mathrm{mM}$ EDTA in $50 \mathrm{mM}$ TRIS-HCl buffer $\left(\mathrm{pH} \mathrm{7.0)}\right.$ and the remaining dipeptidase activity measured on dipeptides at $37^{\circ} \mathrm{C}$ for $15 \mathrm{~min}$. in $50 \mathrm{mM}$ TRIS-HCl buffer ( $\mathrm{pH} \mathrm{7.0)}$ further incubated in divalent cation $1 \mathrm{mM}$ solutions. Activity is expressed as a percentage of the control.

\begin{tabular}{cc}
\hline $\begin{array}{c}\text { Addition of } 1 \mathrm{mM} \\
\text { cations after } 0.01 \mathrm{mM} \\
\text { EDTA inhibition }\end{array}$ & $\begin{array}{c}\text { Dipeptidase } \\
\text { activity as p. 100 } \\
\text { of control }\end{array}$ \\
\hline & \\
$\mathrm{Co}^{++}$ & 120 \\
$\mathrm{Zn}^{++}$ & 105 \\
$\mathrm{Ca}^{++}$ & 84 \\
$\mathrm{Mg}^{++}$ & 65 \\
& 20 \\
\hline
\end{tabular}

pounds having no free N-terminal amino group showed that the enzyme had no carboxypeptidase activity (table 3 ) ; these groups, and particularly N-terminal methionine, are necessary to hydrolyse the dipeptides effectively. Thus, Dipeptidase 1 from S. diacetilactis is a L-Methionyl-amino-acid hydrolase (EC. 3.4.13.12).

TABLE 3

Substrate specificity of Dipeptidase 1

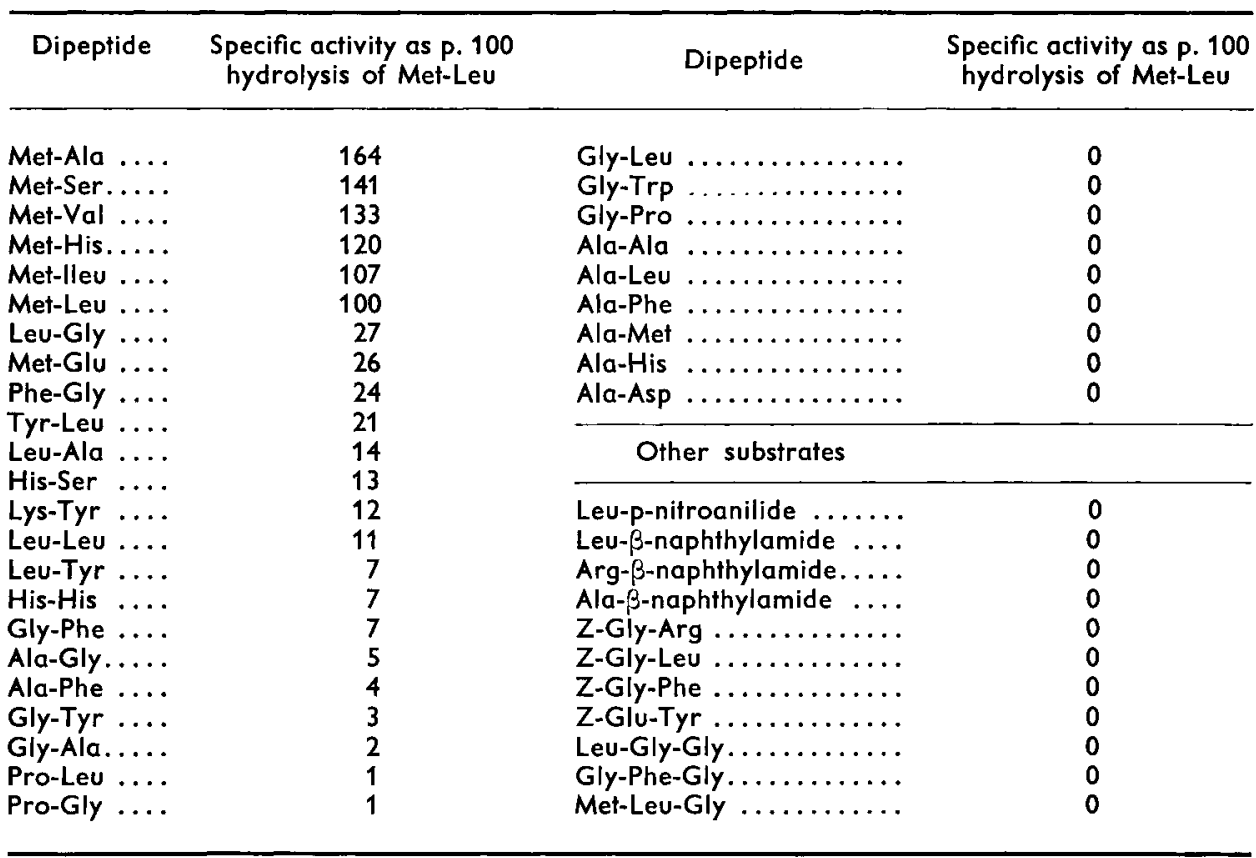


The $K_{m}$ and $k_{\text {cat }}$ values for some of the methionyl dipeptides are shown in Table IV. The $K_{m}$ values were similar for all substrates tested (though Met-Glu showed a poor

\section{TABLE 4}

Kinetic constants for Dipeptidase U-catalysed hydrolysis of methionyldipeptides.

Activity was determined at $37^{\circ} \mathrm{C}$ by measuring liberated L-amino-acids from various dipeptides after ninhydrin reaction. The reaction mixture contained $0.8 \mathrm{ml}$ substrate (from $0.05 \mathrm{mM}$ to $0.5 \mathrm{mM}$ ) in $0.1 \mathrm{M}$ sodium phosphate buffer, $\mathrm{pH} 7.0$ and $0.2 \mathrm{ml}$ of a suitable dilution of enzyme preparation. The incubation time was 10,20 and $30 \mathrm{~min}$. or 1,2 and $3 \mathrm{~h}$ for Met-Glu.

\begin{tabular}{lccc}
\hline Peptides & $\begin{array}{c}K_{\mathrm{m}} \\
(\mathrm{mM})\end{array}$ & $\begin{array}{c}k_{\text {eat }} \\
\left(\mathrm{sec}^{-1}\right)\end{array}$ & $\begin{array}{c}\mathrm{k}_{\text {cat }} / \mathrm{K}_{\mathrm{m}} \\
\left(\mathrm{sec}^{-1} \times \mathrm{mM}^{-1}\right)\end{array}$ \\
\hline Met-Ala..... & 0.33 & 34.6 & 104.8 \\
Met-Val...... & 0.34 & 35.3 & 104 \\
Met-His ...... & 0.56 & 52.7 & 94.1 \\
Met-Ile ...... & 0.39 & 36.5 & 93.5 \\
Met-Ser ...... & 0.43 & 26.9 & 62.6 \\
Met-Leu ..... & 0.68 & 26.3 & 38.7 \\
Met-Glu ...... & 1.33 & 0.19 & 0.14 \\
\hline
\end{tabular}

affinity), but the $k_{\text {cat }}=V_{M} / E$ ) values varied more than 200-fold for Met-Glu. The «proteolytic coefficient» $\left(=k_{\text {cat }} / K_{m}\right)$ was similar for Met-Ala, Met-Val, Met-lle and Met-His, and very weak for Met-Glu (table 4).

\section{TABLE 5}

Amino-acid composition of Dipeptidase 1 from S. diacetilactis. Comparison with various dipeptidases

\begin{tabular}{|c|c|c|c|c|}
\hline Amino-acid & $\begin{array}{l}\text { Dipeptidase from } \\
\text { S. diacetilacfis } \\
\text { (51,000 daltons) }\end{array}$ & $\begin{array}{c}\text { Dipeptidase from } \\
\text { Mycobacterium } \\
\text { phlei } \\
\text { (45,000 daltons) }\end{array}$ & $\begin{array}{l}\text { Renal dipeptidase } \\
\text { (47,200 daltons) }\end{array}$ & $\begin{array}{c}\text { Intestinal } \\
\text { dipeptidase } \\
\text { monomer } \\
\text { (52,000 daltons) }\end{array}$ \\
\hline 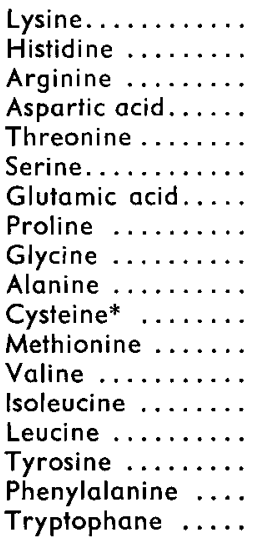 & $\begin{array}{r}26 \\
10 \\
15 \\
49 \\
19 \\
26 \\
56 \\
18 \\
40 \\
35 \\
9 * \\
8 \\
27 \\
20 \\
33 \\
14 \\
16\end{array}$ & $\begin{array}{r}17 \\
8 \\
19 \\
44 \\
24 \\
21 \\
43 \\
20 \\
37 \\
47 \\
3 \\
5 \\
27 \\
20 \\
37 \\
13 \\
15 \\
9\end{array}$ & $\begin{array}{r}29 \\
10 \\
17 \\
39 \\
22 \\
28 \\
43 \\
21 \\
25 \\
32 \\
17 \\
7 \\
27 \\
15 \\
41 \\
12 \\
18 \\
11\end{array}$ & $\begin{array}{r}33 \\
12 \\
17 \\
47 \\
20 \\
28 \\
51 \\
22 \\
41 \\
32 \\
8 \\
9 \\
32 \\
25 \\
44 \\
17 \\
16 \\
9\end{array}$ \\
\hline
\end{tabular}

* This value was determined by analysing the performic acid oxidation product of the Dipeptidase I. 
Amino-acid composition. No significant differences were found between 24 and $72 \mathrm{~h}$ acid hydrolysis. Unfortunately we did not have enough protein forprecise tryptophane determination. Dipeptidase 1 contained many aspartic acid, glutamic acid (or their amides) or glycine residues (table 5) and some methionine, histidine or cysteine residues.

\section{Discussion.}

Until now, dipeptidase of lactic streptococci of the $\mathrm{N}$-group and in particular that of Streptococcus diacetilactis has not been thoroughly studied, although its action has already been demonstrated in these bacteria (Mou et al., 1975 ; Sorhaug and Solberg, 1973).

With an optimum pH of 7.5-8.0, S. diacetilactis dipeptidase is close to the dipeptidases of S. thermophilus (Rabier and Desmazeaud, 1973), Neisseria catarrhalis (Behal and Folds, 1967) Escherichia coli (Haley, 1968), as well as the dipeptidase of Saccharomyces cerevisiae var. ellipsoideus (Cordonnier, 1966), the $\mathrm{pH}$ optimum of brewer's yeast being slightly higher (Röhm, 1974).

S. diacetilactis dipeptidase, as most of the previously studied dipeptidases (Rabier and Desmazeaud, 1973 ; Brown, 1973 ; Johnson and Brown, 1974 ; Röhm, 1974), behaves like a metalloenzyme since EDTA is a potent inhibitor, and this inhibition can be totally or partially suppressed by cations, $\mathrm{Co}^{++}$and $\mathrm{Zn}^{++}$. Because of its relative sensitivity to sodium parachloromercuribenzoate it can be compared with dipeptidases of S. thermophilus (Rabier and Desmazeaud, 1973), N. cotarrhalis (Behal and Folds, 1967) and S. cerevisiae var. ellipsoideus (Cordonnier, 1966).

The molecular weight of $S$. diacetilactis dipeptidase $(51,000$ daltons) is similar to that of S. thermophilus dipeptidase (Rabier and Desmazeaud, 1973) and slightly higher than that of M. phlei (Plancot and Han, 1972) or the renal dipeptidase (Campbell ef al., 1966) which have similar molecular weights of 45000 and 47000 , respectively. The analogy with the two latter dipeptidases is confirmed by comparing their amino acid composition with that of $S$. diacetilactis dipeptidase after acid hydrolysis. The half values of a number of intestinal dipeptidase residues (molecular weight : 104000 daltons) are also indicated in table 5 , the two polypeptide chains constituting this dipeptidase being identical (monomers M.W $=52,000$ daltons ; Noren and Sjöström, 1974). In all these enzymes there are many lysine, aspartic acid (or asparagine), glutamic acid (or glutamine), alanine or leucine residues and a smaller number of histidine, methionine or cysteine ones.

Because of substrate specificity, S. diacefilactis dipeptidase is a L-methionyl-aminoacid hydrolase (EC. 3.4.13.12) analogous to that of E. coli (Brown, 1973) or Neurospora crassa (Johnson and Brown, 1974). For the substrates Met-Ala, Met-Ser or Met-lle, the $K_{m}$ values are very similar. However, the $k_{c a t}$ values measured for $S$. diacetilactis dipeptidase are much lower than those recorded for $E$. coli dipeptidase (Patterson et al., 1973).

The specificity of $\mathrm{S}$. diacetilactis dipeptidase towards $\mathrm{NH}_{2}$-terminal methionine dipeptides shows the importance of the nature of the residues in obtaining good positioning of the substrate dipeptide. The active dipeptidase site must therefore be compos- 
ed of two pockets of very accurate spatial configuration allowing adequate interaction between the amino acid residue in which the $L-\alpha$-amino group is free ( $R_{N}$ pocket) and that of the amino acid with a free carboxyl group ( $R_{C}$ pocket) (Patterson ef al., 1973). L-methionyl-dipeptidase of $S$. diacetilactis is probably fitted with a deep, narrow $R_{N}$ pocket adapted to a linear residue. This would account for the weak hydrolysis of Leu-x-type substrates as compared with Met-x-type substrates. Likewise, the absence of hydrolysis of some substrates with glycyl or alanyl residue into $\mathrm{NH}_{2}$-terminal position could be the result of their inadequate positioning due to the lack of interaction with the $R_{N}$-pocket. Kinetic constants show the importance of residues having a free carboxylic group since the proteolytic coefficient $\left(k_{\text {cat }} / K_{m}\right)$ is 2.7 or 748 times lower with Met-Leu or Met-Glu, respectively, than with Met-Ala (or Met-Val).

S. diacetilactis methionyl-dipeptidase is thus different from the several dipeptidases exhibiting great affinity for dipeptides with $\mathrm{NH}_{2}$-terminal-alanine or glycine (Patterson ef al., 1973 ; Plancot and Han, 1972 ; Noren et al., 1973 ; Behal and Folds, 1967), proline (Akrawi and Bailey, 1976) or cysteine residue (Mc Corquodale, 1963).

The role of the dipeptidase in S. diacetilactis metabolism is unknown. However, in $M$. crassa (Johnson and Brown, 1974), it has been suggested that methionyl dipeptidases might be involved in the liberation of N-terminal methionine from the newlyinitiated proteins. Intracellular dipeptidases, like those of $E$. coli (Simmonds, 1966) and many other bacteria (Payne, 1976), are probably also involved in the breakdown of peptides and proteins, thus participating in the general protein turn-over of the cell as well as in the utilization of the peptides as sources of amino-acids.

Reçu en janvier 1977. Accepté en mars 1977.

Résumé. La purification, les principales propriétés et la spécificité d'action sur différents dipeptides, d'une dipeptidase intracellulaire de $S$. diacetilactis, sont décrites dans ce mémoire.

L'activité optimum de cette enzyme était obtenue entre $\mathrm{pH} \mathrm{7,5}$ et 8,0 en utilisant la Met-Leu, la Phe-Gly ou la Leu-Leu comme substrat. Son poids moléculaire était estimé à 51000 daltons par chromatographie sur gel Sephadex G-100. Cette dipeptidase était stable aux températures inférieures à $50^{\circ} \mathrm{C}$ et dans la zone de $\mathrm{pH} 7,0-8,0$. Elle était totalement inactivée par I'E. D. T. A. 0,01 mM, mais elle pouvait être réactivée por des cations tels que $\mathrm{Co}^{++}$ou $\mathrm{Zn}^{++}$.

Cette enzyme est une dipeptidase vraie car elle n'hydrolyse aucun substrat en dehors des dipeptides. En particulier, elle ne présente aucune activité envers I 5 tripeptides ni les dérivés d'acide aminé, ni les protéines natives ou dénaturées. Les études de spécificité ont montré qu'elle hydrolyse préférentiellement les dipeptides ayant un résidu méthionyle $\mathrm{N}$-terminal (Met-Ala > Met-Val > Met-lleu). On peut donc la classer comme une enzyme de type méthionyle dipeptidase EC 3.4.13.12. Sa composition en acides aminés est assez comparable à celle obtenue pour une dipeptidase de Mycobacterium phlei ou celle d'une dipeptidase rénale.

\section{Références}

AKRAWI A. F., BAILEY G. S., 1976. Purification and specificity of prolyl dipeptidase from bovine kidney. Biochim. biophys. Acia, 422,, 170-178.

ANDREWS P., 1964. Estimation of the molecular weight, of proteins by Sephadex gel-filtration. Biochem. J., 91, 222-233. 
BEHAL F. J., FOLDS J. D., 1967. A comparative study of bacterial alanine amino-hydrolases. Biochem. biophys. Res. Comm., 27, 344-349.

BROWN J. L., 1973. Purification and properties of dipeptidase $M$ from Escherichia coli B. J. biol. Chem., 248, 409-416.

CAMPBELL B. J., LIN Y. C., DAVIS R. V., BALLEW E., 1966. The purification and properties of a particulate renal dipeptidase. Biochim. biophys. Acta, 118, 371-386.

CHRAMBACH A., REISFELD R. A., WICKOFF M., ZACCARI J., 1967. A procedure for rapid and sensitive staining of protein fractionated by polyacrylamide gel-electrophoresis. Anal. Biochem. 20, $150-154$.

CORDONNIER R., 1966. Recherches sur l'amino-carboxypeptidase (dipeptidase) de Saccharomyces cerevisiae var. ellipsoideus. Ann. Technol. Agr., 15, HS I, 1-114.

DAVIS B. J., 1964. Disc electrophoresis II. Method and application to human serum proteins. Ann. N. Y. Acad. Sci., 121, 404-427.

DEIBEL R., SEELEY H. W., 1974. In BUCHANAN R. E., GIBBONS N. E., Bergey's Manual of determinative bacteriology, part 14, p. 490-491, 8 th ed., Williams ond Wilkins Company, Baltimore.

DESMAZEAUD M. J., HERMIER, J. H., 1972. Isolement et détermination de la composition qualitative de peptides issus de la caséine, stimulant la croissance de Streplococcus thermophilus. Eur. J. Biochem., 28, 190-198.

DESMAZEAUD M. J., HERMIER J. H., 1973. Effet de fragments peptidiques du glucagon vis-à-vis de la croissance de Streptococcus thermophilus. Biochimie, 55, 679-684.

DESMAZEAUD M. J., ZEVACO C., 1976. General properties and substrate specificity of an intracellular neutral protease from Streptococcus diacetilactis. Ann. Biol. anim. Bioch. Bioph., 16, 851. 868.

EXTERKATE F. A., 1975. An introductory study of the proteolytic system of Streptococcus cremoris strain HP. Neth. Milk Dairy J., 29, 303-318.

GARVIE E. I., MABBITT L. A., 1956. Acid production in milk by starter cultures. The effect of peptone and other stimulatory substances. J. Dairy Res., 23, 305-314.

HALEY E. E., 1968. Purification and properties of a $\beta$-aspartyl peptidase from Escherichia coli. J. biol. Chem., 243, 5748-5752.

JOHNSON G. L., BROWN J. L., 1974. Partial purification and characterization of two peptidases from Neurospora crassa. Biochim. biophys. Acta, 370, 530-540.

LAYNE E., 1957. In COLOWICK S. P., KAPLAN N. O., Methods in Enzymology, vol. III, p. 451-545. Acad. Press Inc., New-York.

LEWIS W. H. P., HARRIS H., 1967. Human red cell peptidases. Nature, 215, 351-355.

LOWRY O. H., ROSEBROUGH N. J., FARR A. L., RANDALL R. J., 1951. Protein measurement with the Folin phenol reagent. J. biol. Chem., 193, 265-275.

McCORQUODALE D. J., 1963. Some properties of a ribosomal cysteinyl-glycinase of Escherichia coli B. J. biol. Chem., 238, 3914-3920.

MILLER C. G., Mc KINNON K., 1974. Peptidase mutants of Salmonella typhymurium. J. Bacteriol., 120, 355-363.

MOORE S., STEIN W. H., 1954. A modified ninhydrin reagent for the photometric determination of amino-acids and related compounds J. biol. Chem., 211, 907-913.

MORIHARA K., TSUZUKI H., OKA T., 1968. Comparison of the specificities of various neutral proteinases from microorganisms. Arch. Biochem. Biophys., 123, 572-588.

MOU L., SULLIVAN J. J., JAGO G. R., 1975. Peptidase activities in group N streptococci. J. Dairy Res., 42, 147-155.

NOREN O., SJÖSTRÖM H., 1974. Studies on a soluble dipeptidase from pig intestinal mucosa. Structural properties. Acta chem. scand, B28, 787-792.

NOREN O., SJÖSTRÖM H., JOSEFSSON L., 1973. Studies on a soluble dipeptidase from pig infestinal mucosa. I. Purification and specificity. Biochim. biophys. Acta, 327, 446-456.

ORNSTEIN L., 1964. Disc electrophoresis. I. Background and theory. Ann. N. Y. Acad. Sci., 121, 321-349.

PATTERSON E. K., GATMAITAN J. S., HAYMAN S., 1973. Substrate specificity and pH dependence of dipeptidase purified from Escherichia coli B and from mouse ascites tumor cells. Biochemistry, 12, 3701-3709.

PAYNE J. W., 1976. Peptides and micro-organisms. Adv. Microbiol. Physiol., 16, 55-113. 
PLANCOT M. T., HAN K. K. 1972. Purification and characterization of an intracellular dipeptidase from Mycobacterium phlei. Eur. J. Biochem., 28, 327-333.

RABIER D., DESMAZEAUD M. J., 1973. Inventaire des différentes activités peptidasiques intracellulaires de Streptococcus thermophilus. Purification et propriétés d'une dipeptide-hydrolase et d'une amino-peptidase. Biochimie, 55, 380-404.

REITER B., ORAM J. D., 1962. Nutritional studies on cheese starters. I. Vitamins and amino-acid requirements of single strain starters. J. Dairy Res., 29, 63-77.

RENE A. M., CAMPBELL B. J., 1969. Amino-acid composition and effect of $\mathrm{pH}$ on the kinetic parameters of renal dipeptidase. J. Biol. Chem., 244, 1445-1450.

RÖHM K. H., 1974. Properties of a highly purified dipeptidase (EC. 3.4.13. ?) from Brewer's yeast. Hoppe-Seyler's Z. Physiol. Chem., 355, 675-676.

RONCARI G., ZUBER H., 1969. Thermophilic aminopeptidases from Bacillus sfearothermophilus. I. Isolation, specificity and general properties of the thermostable aminopeptidase I. Int. J. Protein Res., 1, 45-61.

SIMMONDS S., 1966. The role of dipeptidases in cells of Escherichia coli strain K-12. J. biol. Chem., 241, 2502-2508.

SJÖSTRÖM H., NOREN O., JOSEFSSON L., 1973. Purification and specificity of pig intestinal prolidase. Biochim. Biophys. Acta, 327, 457-470.

SORHAUG T., SOLBERG P., 1973. Fractionation of dipeptidase activities of Streptococcus lactis and dipeptidase specificity of some lactic acid bacteria. Appl. Microbiol., 25, 388-395.

SPECK M. L., MC ANELLY J. K., WILBUR J. D., 1958. Variability in response of lactic streptococci to stimulants in extracts of pancreas liver, and yeast. J. Dairy Sci., 41, 502-507.

VALLES E., MOCQUOT G., 1968. Préparation de suspensions concentrées et congelées de bactéries lactiques thermophiles. Le lait, 48, 631-543. 